\title{
KEBIJAKAN PIDANA KEJAKSAAN REPUBLIK INDONESIA DALAM PENANGANAN PERKARA TINDAK PIDANA KORUPSI DENGAN KERUGIAN KECIL (PATTY CORRUPTION) DENGAN PENDEKATAN KEMANFAATAN
}

\author{
I Made Agus Mahendra Iswara. ${ }^{1)}$,I Ketut Kartika Widnyana, ${ }^{2}$ \\ Made Gede Arthadana, ${ }^{3)}$ \\ 1)2),Kejaksaan Negeri Denpasar, ${ }^{3)}$ Fakultas Hukum, Program Studi Hukum Adat, \\ Universitas Hindu Indonesia \\ Email: iswara1908@gmail.com ${ }^{1)}$,pasekpenyarikanpasek@gmail.com ${ }^{2)}$ \\ arthadanakusuma20@,gmail.com ${ }^{3)}$
}

\begin{abstract}
The first discussion is related to the theoretical study of handling criminal cases through the economic approach of law that the Economic Analysis of Law theory or what is referred to as the application of economic theory to legal analysis is a theory that uses economic concepts to explain the effects of the law itself. Several economic concepts used in the study of criminal law policies are: Cost-Benefit Analysis, Behavioral theory, Efficiency-Pareto Optimal. The second discussion is related to the policy of the Prosecutor's Office of the Republic of Indonesia in handling cases of corruption with small losses (patty corruption) with a benefit approach that the Indonesian Attorney General's Office in carrying out its duties and functions, especially in terms of handling corruption cases, issued several internal regulations related to efforts to eradicate corruption through a beneficial approach, namely: Circular Letter of the Junior Attorney General for Special Crimes Number: B-1113/F/Fd.1/05/2010 dated 18 May 2010, Circular Letter of the Junior Attorney General for Special Crimes No: B765/F/Fd/04/2018 20 April 2018 May 2018, Circular Letter of the Junior Attorney General for Special Crimes Number: B-945/F/Fjp/05/2018 May 04, 2018.
\end{abstract}

Keywords: Prosecutors' Criminal Policy, Corruption Handling, Benefit Approach

\begin{abstract}
Abstrak
Pembahasan pertama terkait dengan kajian teoritis penanganan perkara pidana melalui pendekatan economy approach of law bahwa Teori Economy Analysis of Law atau yang disebut sebagai aplikasi teori ekonomi untuk analisis hukum merupakan teori yang mempergunakan konsep-konsep ekonomi untuk menjelaskan efek dari hukum itu sendiri. Beberapa konsep ekonomi yang dipergunakan dalam kajian kebijakan hukum pidana yaitu : Cost-Benefit Analysis, Behavioral theory, Efisiensi-Pareto Optimal. Pembahasan kedua terkait dengan kebijakan Kejaksaan Republik Indonesia dalam penanganan perkara tindak pidana korupsi dengan kerugian kecil (pattycorruption) dengan pendekatan kemanfaatan bahwa Bahwa Kejaksaan RI dalam pelaksanaan tugas dan fungsinya,
\end{abstract}


khususnya dalam hal Penanganan perkara tindak pidana korupsi mengeluarkan beberapa aturan internal yang berhubungan dengan upaya pemberantasan korupsi melalui pendekatan kemanfaatan, yaitu : Surat Edaran Jaksa Agung Muda Tindak Pidana Khusus Nomor : B-1113/F/Fd.1/05/2010 tanggal 18 Mei 2010, Surat Edaran Jaksa Agung Muda Tindak Pidana Khusus No : B-765/F/Fd/04/201820 April 2018 Mei 2018, Surat Edaran Jaksa Agung Muda Tindak Pidana Khusus Nomor : B-945/F/Fjp/05/2018 Tanggal 04 Mei 2018.

Kata Kunci :Kebijakan Pidana Kejaksaan, Penanganan Korupsi, Pendekatan Kemanfaatan

\section{A. Pendahuluan}

Korupsi merupakan permasalahan yang bersifat global yang menjangkiti seluruh negara. Begitu pula Indonesia, korupsi tumbuh dan berkembang mulai dari pusat sampai dengan derajat pemerintah daerah. Layaknya gurita, korupsi semakin kuat melilit dan mencengkram sendi-sendi negara ini. Pasca reformasi korupsi menyebar, massif dan banyak, dibandingkan pada masa orde baru dan orde lama korupsi tersentralisasi (terpusat) pada pihak tertentu dan kroninya, sedangkan pada era reformasi ditandai dengan adanya desentralisasi, keuangan negara / perekonomian negara maka jenis korupsi dapat dibagi menjadi 3 (tiga) jenis yaitu (a) korupsi dengan kerugian negara / perekonomian super besar (mega corruption) seperti kasus korupsi ASABRI dan JIWASRAYA yang mana negara Cq. BUMN mengalami kerugian triliunan rupiah, (b) korupsi dengan kerugian besar (high corruption) seperti korupsi pengadaan barang / jasa pada umumnya, dan (c) korupsi dengan kerugian negara / perekonomian kecil (patty corruption) seperti pungli oleh pejabat.

setiap orang memanfaatkan jabatan dan waktunya untuk mengeruk keuntungan sebanyak-banyaknya. Hal ini terjadi dari tingkat pusat sampai dengan tingkat terendah.

Bahwa korupsi yang terjadi massif disetiap lini berdampak pada budaya masyarakat yang menganggap korupsi itu merupakan suatu kewajaran. Hal ini mendorong niat buruk setiap pihak pemilik kekuasaan dan kewenangan untuk melakukan rasuah terhadap setiap kegiatankegiatan yang dilakukan. Apabila kita melihat pada jumlah kerugian 
Jurnal Hukum Saraswati (JHS)Volume. 03, Nomor 02, (2021)

FAKULTAS HUKUM UNMAS DENPASAR

ISSN (Cetak) : 2715-758X ISSN (Online): 2720-9555

Doi: https://doi.org/10.36733/jhshs.v2i2

https://e-journal.unmas.ac.id/index.php/JHS

Bahwa problematik yang setimpal dengan perbuatannya) dan dihadapi oleh penegak hukum droil ne done,pluis que soit demaunde khususnya dalam pemberantasan (hukum memberi tidak lebih dari yang korupsi salah satunya ketimpangan antara anggaran dengan jumlah perkara yang dianggarkan. Ditambah missconceptual terkait dengan tujuan penegakan hukum dalam pemberantasan korupsi. Bahwa tujuan pemberantasan tindak pidana korupsi disamping memberikan pembalasan, memberikan detterent effect baik secara umum maupun khusus juga bertujuan restorasi yaitu pemulihan kerugian keuangan negara. Namun paradigma penghukuman sebagai upaya pembalasan masih kental terasa dalam pemberantasan korupsi.

Permasalahan korupsi dengan jumlah kerugian keuangan negara yang kecil menimbulkan pro dan kontra dalam masyarakat disatu sisi korupsi merupakan patologi legal sosial disisi lain aspek ekonomi (pemulihan) menjadi pertimbangan dalam menyelesaikan permasalahan tersebut. Bahwa seharusnya kebijakan pemberantasan korupsi didasarkan pada asas subsosialitas sesuai dengan adigium Culpue poena par esto(jatuhkanlah hukuman yang dibutuhkan).

Salah satu lembaga penegak hukum yang memiliki kewenangan dalam pemberantasan tindak pidana korupsi adalah Kejaksaan Republik Indonesia (selanjutnya disebut Kejaksaan RI). Pasal 2 ayat (1) Undang-Undang Republik Indonesia Nomor 16 Tahun 2004 Tentang Kejaksaan Republik Indonesia (selanjutnya disebut UU Kejaksaan RI) merupakan "lembaga pemerintah yang melaksanakan kekuasaan negara di bidang penuntutan serta kewenangan lain berdasarkan undang-undang". Pasal ini memberikan kewenangan kepada Kejaksaan RI tidak hanya berwenang melakukan penuntutan namun juga terdapat beberapa kewenangan lainnya yang salah satu fungsinya melakukan upaya penyidikan tindak pidana korupsi.

Bahwa diperlukan pengkajian mengenai kebijakan hukum pidana (penal policy) Lembaga Kejaksaan RI dalam penanganan perkara tindak pidana korupsi dengan jumlah kerugian keuangan negara kecil (patty 
Jurnal Hukum Saraswati (JHS)Volume. 03, Nomor 02, (2021)

FAKULTAS HUKUM UNMAS DENPASAR

ISSN (Cetak) : 2715-758X ISSN (Online): 2720-9555

Doi: https://doi.org/10.36733/jhshs.v2i2

https://e-journal.unmas.ac.id/index.php/JHS

corruption). Berdasarkan uraian diatas maka para penulis tertarik untuk melakukan pengkajian.

\section{B. Metode Penelitian}

Metode penelitian yang digunakan dalam penulisan jurnal ilmiah ini adalah jenis metode penelitian hukum normatif, yaitu penelitian yang dilakukan dengan cara atau berfokus kepada norma, asas-asas hukum, penelitian terhadap sistematika hukum, penelitian terhadap taraf sinkronisasi hukum, penelitian sejarah hukum, dan menganalisa data sekunder (bahan hukum). ${ }^{1}$

Bahan hukum yang digunakan adalah bahan hukum primer dan sekunder. Bahan hukum primer merupakan bahan hukum yang bersifat autoritatif berupa peraturan perundangundangan. Bahan hukum sekunder berupa literature terkait dengan hukum pidana. ${ }^{2}$

\section{Pembahasan}

\footnotetext{
${ }^{1}$ MuktiFajardanYuliantoAchmad, 2010,DualismePenelitianHukumNormatifdanE mpiris, PustakaPelajar, Yogyakarta, h. 153

${ }^{2}$ Soerjono Soekanto dan Sri Mamudji, 2011, Penelitian Hukum Normatif Suatu Tinjauan Singkat,Cet. VI, PT. Raja Grafindo Persada, Jakarta, h.13
}

\subsection{Kajian Teoritis Penanganan}

Perkara Pidana Melalui Pendekatan

\section{Economy Approach Of Law}

Tentang kaitan antara hukum dengan ekonomi dibuka dengan pemikiran Talcott Parsons. Talcott Parsons membahas keterkaitan antara hukum dengan bidang-bidang lain dalam sistem sosial. Parsons menempatkan hukum sebagai subsistem dalam sistem sosial yang lebih besar. Disamping hukum, terdapat subsub sistem lain yang memiliki logika dan fungsi yang berbeda-beda, subsistem dimaksud adalah budaya, politik, dan ekonomi. ${ }^{3}$ Hukum menunjuk pada aturan-aturan sebagai aturan main bersama (Rule of game). Fungsi utama sub-sistem ini mengkoordinir dan mengontrol segala penyimpangan agar sesuai dengan aturan main. ${ }^{4}$ Sedangkan ekonomi menunjuk pada sumber daya materil yang dibutuhkan menopang hidup sistem.Tugas sub-sistem ekonomi adalah menjalankan fungsi adaptasi

\footnotetext{
${ }^{3}$ Bernald L. Tanya, Yoan N. Simanjuntak \& Markus Y. Hage, 2012, Teori Hukum Strategi Tertib Manusia Lintas Ruang dan Generasi, Genta Publishing, Yogyakarta, hal. 30. (selanjutnya dsebut Bernald L. Tanya, $\mathrm{dkk})$

${ }^{4}$ Ibid.
} 
Jurnal Hukum Saraswati (JHS)Volume. 03, Nomor 02, (2021)

FAKULTAS HUKUM UNMAS DENPASAR

ISSN (Cetak) : 2715-758X ISSN (Online): 2720-9555

Doi: https://doi.org/10.36733/jhshs.v2i2

https://e-journal.unmas.ac.id/index.php/JHS

berupa kemampuan menguasai saranasarana dan fasilitas untuk kebutuhan sistem. ${ }^{5}$ Disini hukum berfungsi "menjinakkan"sub-sub sistem lainnya agar berjalan sinergis sedangkan subsistem ekonomi berfungsi melahirkan terobosan-terobosan baru yang bisa saja asing dari ukuran pola-pola ideal budaya ${ }^{6}$

Hubungan interaksi antara hukum dan ekonomi juga dikemukakan oleh Cooter dan Ulen yang menegaskan bahwa interaksi antara ilmu hukum dan ilmu ekonomi tidak dapat dipisahkan, karena keduanya mempunyai persamaan dan keterikatan di dalam teori-teori keilmuan tentang perilaku (scientific theories of behavior). Menurut mereka, ilmu ekonomi menyediakan acuan normatif untuk mengevaluasi hukum dan kebijakan, sementara hukum bukan hanya berupa misteri rahasia, argument-argumen teknikal, namun berupa alat untuk mencapai tujuantujuan sosial yang penting. Ilmu ekonomi memprediksi terhadap

$\begin{array}{cccc}{ }^{5} \text { Ibid. } & & \\ { }^{6} \text { T.J. } & \text { Gunawan, 2015, Konsep }\end{array}$
Pemidanaan Berbasis Nilai Kerugian Ekonomi, GENTA Press, Yogyakarta, h.16-17. efisiensi kebijakan. ${ }^{7}$ Bahwa Teori Hukum sebagai Mekanisme Integrasi menggambarkan bagaimana hubungan ilmu ekonomi dalam membahas persoalan hukum khususnya dalam pembiayaan penanganan patty corruption dikaji dari aspek biaya (cost) dan manfaatnya (benefit).

Sedangkan teori Utilitarisme atau yang dikenal dengan Teori Hukum sebagai penyokong kebahagiaan ${ }^{8}$. Jeremy Bentham menyatakan bahwa hukum sebagai tatanan hidup bersama harus diarahkan untuk menyokong si "raja suka" (kebahagiaan) dan serentak mengekang si "raja duka". Dengan kata lain, hukum harus berbasis manfaat bagi kebahagiaan manusia. ${ }^{9}$ Menurut McCourbey dan White, analisis ekonomi dalam hukum merupakan perkembangan model dari paham utilitarian. Hal ini didasarkan kepada konsep bahwa seseorang adalah makhluk rasional sehingga tindakannya merefleksikan motivasi dan nilainya untuk memperoleh

\footnotetext{
${ }^{7}$ Fajar Sugianto, 2015,Economic Approach to Law Seri Analisis ke-ekonomian Tentang Hukum, seri II, Prenadamedia, Jakarta, h.31. (selanjutnya disebut Fajar Sugianto I)

${ }^{8}$ Bernald L. Tanya, dkk, Op.Cit, h.82.

${ }^{9}$ Ibid, h. 83 .
} 
Jurnal Hukum Saraswati (JHS)Volume. 03, Nomor 02, (2021)

FAKULTAS HUKUM UNMAS DENPASAR

ISSN (Cetak) : 2715-758X ISSN (Online): 2720-9555

Doi: https://doi.org/10.36733/jhshs.v2i2

https://e-journal.unmas.ac.id/index.php/JHS

46

utilitas. Dalam ekonomi, seseorang selalu dinilai sebagai makhluk yang rasional untuk memperoleh manfaat sebesar-besarnya

dengan

memanfaatkan

ketersediaan

kesempatan atau sumber daya yang dimiliki. Kesempatan tersebut bisa diintervensi dengan suatu kebijakan untuk memberi insentif atau disinsentif. Pemidanaan dalam hal ini bertujuan untuk memberikan disinsentif bagi pelaku tindak pidana. Dengan demikian, pelaku diharapkan akan bertindak secara rasional untuk tidak melakukan tindak pidana karena disinsentif berupa pemidanaan atau hukuman tidak bermanfaat bagi dirinya. ${ }^{10}$ Bahwa Teori Utilitarisme tersebut menjelaskan bagaimana dalam penanganan patty corruption dicari cara yang memberikan kabahagian (keuntungan) terbesar serta menghilangkan kemudaratan dalam penanganan perkaranya.

Teori Economy Analysis of Law atau yang disebut sebagaiaplikasi teori ekonomi untuk analisis hukum merupakan teori yang mempergunakan

${ }^{10}$ Choky Ramadhan, 2016, Pengantar Analisis Ekonomi dalam Kebijakan Pidana di Indonesia, Institue for Criminal Justice Reform (ICJR), Jakarta, h.23-24. konsep-konsep ekonomi untuk menjelaskan efek dari hukum itu sendiri. ${ }^{11} \quad$ Analisa ilmu ini menggunakan kerangka teoritis metode ilmu ekonomi guna menganalisis aturan dan hukum yang memungkinkan menarik kesimpulan tentang keinginan manusia dan segala konsekuensi dari segi hukum dan bagaimana sebaiknya bentuk pengaturan hukumnya. Dari pendekatan analisis ekonomi terhadap hukum yang mempergunakan teoriteori ekonomi yang eksak sehingga penelitian ini dapat "memprediksi" berbagai kemungkinan reaksi tingkah laku manusia terhadap pemberlakuan suatu aturan hukum. ${ }^{12}$

Bahwa teori ini mendukung hubungan antara hukum dan ekonomi dalam melakukan analisa terhadap efektivitas hukum/aturan hukum dengan menggunakan pertimbangan ekonomi untuk mengetahui apakah aturan tersebut dapat berjalan dengan efektif atau tidak, maka logislah jika hasil analisa tersebut mengarah pada pembentukan sistem hukum yang memperhatikan variable sistem

\footnotetext{
11 T.J Gunawan, Op.Cit, h.21.
}

${ }^{12}$ Ibid, h..22-23. 
ekonomi. Beberapa konsep ekonomi yang dipergunakan dalam kajian kebijakan hukum pidana yaitu :

\section{Cost-Benefit Analysis}

Dalam konsep ekonomi, seseorang melakukan analisis untung-rugi (cost-benefit analysis) dalam mengambil keputusan dan bertindak. Hal ini karena seseorang diasumsikan rasional ingin menghasilkan manfaat sebesarbesarnya. Dalam cost-benefit analysis (CBA), suatu tindakan asumsinya dilakukan ketika keuntungan yang diperoleh lebih tinggi dari kerugian atau biaya yang ditanggung. ${ }^{13}$ Alfred Marshall menggagas CBA untuk menyusun proposal proyek. Marshall menghitung biaya yang dapat diukur serta keuntungan yang dapat diperoleh. Konsep ini kemudian berkembang untuk menentukan kebijakan publik yang dapat menghasilkan manfaat sebesarbesarnya bagi masyarakat. ${ }^{14}$ Misalnya, seseorang menghitung potensi kerugian berupa hukuman sehingga mengurungkan niatnya melakukan tindak pidana. Jika seseorang dipidana, dirinya tidak hanya dirampas kemerdekaannya dan dikurung di dalam sel sempit, tetapi juga akan kehilangan penghasilan.

2. Behavioral theory

Behavioral theory atau teori perilaku juga dibahas dalam analisis ekonomi. Teori ini memiliki keterkaitan dengan cost-benefit analysis (CBA). Teori Perilaku memprediksi perilaku seseorang dalam merespon insentif atau keuntungan/manfaat. Prediksi terhadap perilaku ini menjadi salah satu pertimbangan dalam menentukan hukum atau kebijakan. Saat ini, pendekatan terhadap perilaku sedang berkembang di analisis ekonomi terhadap hukum pidana. Perilaku manusia dapat diukur dan dinilai dengan penelitian psikologi baik secara empiris maupun eksperimen. ${ }^{15}$ Ciri khas dari behavioral theory adalah menggunakan eksperimen dan penelitian empirik untuk membuktikan keberhasilan kebijakan berdasarkan teori pilihan rasional (rational choice theory). Eksperimen dan penelitian empirik ini membantu penyusun kebijakan yang tepat sasaran.Keduanya mengumpulkan bukti di masyarakat terhadap pelaksanaan dan dampak dari suatu kebijakan. Dengan demikian, efektifitas kebijakan dapat diuji dan diperbarui untuk menghasilkan perubahan masyarakat yang diharapkan. ${ }^{16}$

3. Efisiensi-Pareto Optimal

Richard Posner menganalogikan tindak pidana dan pemidanaan dalam konsep dasar efisiensi. Dalam ekonomi sering disebut Pareto efisiensi (optimal) yang terkait dengan kepuasan preferensi individu. Kondisi pareto efisien terjadi apabila redistribusi atau peralihan sumber daya terjadi tanpa merugikan individu lain. Oleh karenanya, Posner menyatakan bahwa tindak pidana adalah tindakan yang tidak efisien
${ }^{13}$ Choky Ramadhan, Op.Cit, h.24.
${ }^{14}$ Ibid, h.25.

\footnotetext{
${ }^{15} \mathrm{Ibid}$, h.26.

${ }^{16}$ Ibid, h.28.
} 
Jurnal Hukum Saraswati (JHS)Volume. 03, Nomor 02, (2021)

FAKULTAS HUKUM UNMAS DENPASAR

ISSN (Cetak) : 2715-758X ISSN (Online): 2720-9555

Doi: https://doi.org/10.36733/jhshs.v2i2

https://e-journal.unmas.ac.id/index.php/JHS

karena adanya pemaksaan perpindahan sumber daya yang merugikan pihak lain. Dengan demikian, hukum pidana ada untuk mencegah tindakan dan keadaan yang tidak efisien tersebut. ${ }^{17}$

Sedangkan M. Adi Togarisman

menjelaskan bahwa Sistem Hukum Indonesia yang telah memiliki Regulasi Tindak Pidana Korupsi berdasarkan Undang-Undang Republik Indonesia Nomor 31 Tahun 1999 Tentang Pemberantasan Tindak Pidana Korupsi sebagaimana diubah dengan Undang-Undang Republik Indonesia Nomor 20 Tahun 2001 Tentang Perubahan atas UndangUndang Republik Indonesia Nomor 31 Tahun 1999 Tentang Pemberantasan Tindak Pidana Korupsi Jo. UndangUndang Republik Indonesia Nomor 7 Tahun 2006 Tentang Pengesahan United Nations Convention Againts Corruption (UNCAC) 2003 sebagai Undang-Undang. Berdasarkan sistem hukum tersebut, diperlakukan analisis terhadap kerugian keuangan negara untuk pembaharuan hukum di Indonesia khususnya penanganan

\footnotetext{
${ }^{17} \mathrm{Ibid}, \mathrm{h} .29$.
}

Tindak Pidana Korupsi. ${ }^{18}$ Dengan muatan substansi sebagai berikut :

1. Daya eliminasi terhadap terjadinya benturan hukum antara Undang-Undang Keuangan Negara yaitu UU $17 / 2003$, UU $1 / 2004$ dan UU $15 / 2004$ serta UU 19/2003 dan UU 40/2007 dengan UU 31/1999 Jo. UU 20/2001 agar tidak menyalahi asas principle of legality;

2. Kemampuan pencegahan terhadap terjadinya "judicial dictatorship" dalam proses peradilan Tindak Pidana Korupsi yang bersumber kepada tafsir hukum dari hakim yang sering mengabaikan pertimbanganpertimbangan kontekstual dari perkara;

3. Kemampuan mengurangi disparitas yang dianggap sebagai bentuk ketidakadilan dalam penetapan tuntutan pidana, maupun putusan hukuman pidana pada peradilan tindak pidana korupsi di Indonesia;

4. Kemampuan untuk meningkatkan efisiensi ekonomi dalam pembiayaan penanganan tindak pidana korupsi dibandingkan jumlah pengembalian kerugian keuangan negara dengan rasionalitas dari perspektif waktu;

5. Dapat menangani terjadinya peralihan dari ranah hukum pidana e ranah hukum perdata sebagaimana yang diatur dalam Pasal 32, 33, 34 dan Pasal $38 \mathrm{C}$

\footnotetext{
${ }^{18} \mathrm{M} . \quad$ Adi Toegarisman, 2018, Pemberantasan Korupsi Dalam Proyek Strategis Nasional, Kompas Media, Jakarta, h.
} 9. 
UU 31/1999 Jo. UU 20/2001 secara lebih efektif dan efesien;

6. Dapat menjadi faktor penguatan UU Tipikor karena didasarkan kepada substansi regulasi, strategi dan standar hukum yang dimuat dalam UNCAC 2003.

Bahwa penganalisisan terhadap kerugian keuangan negara dalam pembaharuan hukum dalam hal penanganan korupsi sebagaimana di sebutkan oleh M. Adi Togarisman merupakan suatu analisis yang mempergunakan pendekatan ekonomi. Hal ini dapat dilihat dari "obyek" penganalisisan yaitu "kerugian Keuangan Negara".

\subsection{Kebijakan Kejaksaan Republik}

\section{Indonesia Dalam Penanganan}

Perkara Tindak Pidana Korupsi Dengan Kerugian Kecil (Patty

\section{Corruption) dengan Pendekatan}

\section{Kemanfaatan}

Bahwa penanganan perkaraperkara patty corruption menimbulkan persoalan bagi penanganan perkaranya bagi institusi Kejaksaan khususnya yang ada didaerah. Persoalan inilah yang sebagian besar dihadapi oleh Kejaksaan RI yang ada didaerah dimana anggaran penanganan perkaranya terbatas, disamping akses pengadilan Tipikornya yang berbeda
pulau.Bahwa anggaran / pembiayaan (cost) dalam proses penegakan hukum memiliki peran yang penting. Hal ini sesuai dengan pendapat Romli Atmasasmita yang menyatakan :

"Sistem Peradilan Pidana (SPP) sebagai macro level meliputi 5 (lima) unsur yaitu hukum (tertulis dan tidak tertulis), kelembagaan, keuangan, budaya (culture), dan kondisi geografi. Kelima unsur tersebut merupakan sarana penguat peradilan pidana sebagai suatu sistem. Hukum Acara Pidana harus dilihat secara holistic karena efektif dan efesien tidaknya penerapan hukum acara pidana sebagai salah satu subsistem dari SPP sangat tergantung pada hubungan kordinasi dan sinkronisasi baik secara kelembagaan, budaya, dan anggaran biaya yang diperlukan untuk efisiensi dan efektivitas keberhasilan sistem peradilan pidana secara keseluruhan, maka tujuan pembentukan sistem peradilan pidana tidak dapat dicapai dengan baik". ${ }^{19}$

Bahwa berdasarkan penjelasan tersebut, diketahui bahwa anggaran (cost) dan kondisi geografi memiliki kedudukan yang signifikan dalam kesuksesan suatu penegakan hukum

\footnotetext{
${ }^{19}$ Jan. S. Maringka, 2017, Reformasi Kejaksaan dalam Sistem Hukum Nasional, Sinar Grafika, Jakarta, h.40-41.
} 
Jurnal Hukum Saraswati (JHS)Volume. 03, Nomor 02, (2021)

FAKULTAS HUKUM UNMAS DENPASAR

ISSN (Cetak) : 2715-758X ISSN (Online): 2720-9555

Doi: https://doi.org/10.36733/jhshs.v2i2

https://e-journal.unmas.ac.id/index.php/JHS

\section{0}

khususnya penangana perkara tindak pidana korupsi. Dimana pembiayaan berperan dalam mendukung kegiatan penegakan hukum serta kondisi geografis menentukan mengenai besar beban pembiayaan yang diperlukan.

Bahwa kita tidak dapat memungkiri bahwa hukum tidak dapat eksis, dan oleh karena itu tidak dapat dipelajari dalam ruang yang kosong. Hukum terletak dalam ruang sosial yang dipengaruhi oleh kekuatankekuatan diluar hukum. ${ }^{20}$ Oleh sebab itu, tidak mampu berdiri sendiri tanpa ditopang oleh ilmu lainnya. Salah satu ilmu bantu hukum adalah ilmu ekonomi. Bagaimana hubungan ilmu hukum dan ilmu ekonomi ? Bahwa kedua ilmu tersebut memiliki sinergitasdimana kedua ilmu tersebut berkaitan dengan perilaku manusia. Secara ilmu hukum mengatur tentang perilaku manusia sedangkan ilmu ekonomi mempelajari perilaku manusia dalam memenuhi

${ }^{20}$ I Made Agus Mahendra Iswara, 2013, Mediasi Penal Penerapan Nilai-Nilai Restorative Justice dalam Penyelesaian Tindak Pidana Adat Bali, Tesis Program Studi Hukum dan Sistem Peradilan Pidana Pasca Sarjana Fakultas Hukum Universitas Indonesia, Jakarta, h. 20. kebutuhannya. $^{21}$ Richard A. Posner berpendapat bahwa :

"Ilmu ekonomi merupakan ilmu pengetahuan tentang pilihan rasional di tengah-tengah keterbatasan sumber yang diinginkan manusia. Tugas ilmu ekonomi untuk menggali implikasi-implikasi terhadap dasar pemikiran bahwa manusia sebagai mahluk rasional selalu menginginkan perbaikan di kehidupannya". ${ }^{22}$

Bahwa analisa ekonomi terhadap hukum dikenal sebagai Economic Analysis of Law. Stanford Encyclopedia of Philosophy memberikan definisi Economic Analysis of Law sebagai "Economic Analysis of Law applies the tools of mocroeconomic theory to the analysis of legal rules and institutions (analisis ekonomi atas hukum merupakan studi yang menerapkan alat-alat teori ekonomi untuk menganalisis aturanaturan dan lembaga hukum). ${ }^{23}$

Melihat Karakteristik Tindak Pidana Korupsi yang merupakan

21 Fajar Sugianto, 2014, Economic Analysis of Law : Seri Analisis Keekonomian Tentang Hukum Seri 1 Kencana, Jakarta, h.35 (selanjutnya disebut Fajar Sugianto II).

${ }^{22}$ Ibid.

23 M. Adi Toegarisman, 2016, Pemberantasan Korupsi dalam Paradigma Efisiensi, Kompas Media Nusantara, Jakarta, h.89 
Jurnal Hukum Saraswati (JHS)Volume. 03, Nomor 02, (2021)

FAKULTAS HUKUM UNMAS DENPASAR

ISSN (Cetak) : 2715-758X ISSN (Online): 2720-9555

Doi: https://doi.org/10.36733/jhshs.v2i2

https://e-journal.unmas.ac.id/index.php/JHS

51

Tindak Pidana yang beraspek ekonomi, dimana ada kerugian keuangan negara dan/atau perekonomian negara yang ditimbulkannya. ${ }^{24}$ Oleh karenanya tidak salah dalam penanganan patty corruption perlu dilakukan analisa tidak hanya dalam konteks kepastian hukum (teknis yuridis) tentang benar atau salahnya suatu perkara namun juga perlu dilakukan analisa secara ekonomi. Hal senada disampaikan Romli Atmasasmita \& Kodrat Wibowo

Diperlukan paradigma hukum baru dalam memandang masalah hukum. Paradigma baru yang dimaksud adalah pergeseran dari paradigma hukum berbasis teori moral (moral theory) yaitu penilaian perilaku manusia atas dasar, "benar (right) atau salah (wrong), kepada paradigma hukum berbasis analisa ekonomi mikro "cost and benefit ratio". Peniliaian moral harus dikombinasikan / dilengkapi dengan parameter, sejauh mana kebenaran dan kesalahan perilaku manusia dapat dicegah atau diatasi dengan mempertimbangkan implikasi atas dasar "cost and benefit ratio" didalam usaha pemerintah melindungi kepentingan

${ }^{24}$ Tim Peneliti Pusat Litbang Kejagung, Penghentian Penyidikan dan Penuntutan Perkara Korupsi dalam Kaitannya dengan Asas Kepastian Hukum, Keadilan, dan Kemanfaatan, dalam Jurnal Bina Adhyaksa, Vol. II, No. 1, Maret 2011, h.74

masyarakat, korban, dan pelaku (tindak pidana) serta masyarakat luas. $^{25}$

Bahwa Kejaksaan RI dalam pelaksanaan tugas dan fungsinya, khususnya dalam hal Penanganan perkara tindak pidana korupsi mengeluarkan beberapa aturan internal yang berhubungan dengan upaya pemberantasan korupsi melalui pendekatan kemanfaatan, yaitu :

- Surat Edaran Jaksa Agung Muda Tindak Pidana Khusus Nomor : B1113/F/Fd.1/05/2010 tanggal 18 Mei 2010 perihal Prioritas dan pencapaian dalam penanganan perkara tindak pidana korupsi, bahwa salah satu poin yang perlu diperhatikan dalam penanganan perkara Tindak Pidana Korupsi berdasarkan SE-JAMPIDSUS B1113 adalah "memprioritaskan pengungkapan perkara yang bersifat Big Fish (Berskala besar) dan still going on (yang dilakukan secara terus menerus) serta "mengedepankan penggunaan pendekatan Restorative Justice dalam penanganan perkara yang nilai kerugian keuangan negaranya kecil".

- Surat Edaran Jaksa Agung Muda Tindak Pidana Khusus No : B765/F/Fd/04/201820 April 2018 Mei 2018 Perihal Petunjuk Teknis Penanganan Perkara Tindak Pidana Korupsi Tahap Penyelidikan yang

25 Romly Atmasasmita \& Kodrat Wibowo, 2016, Analisis Ekonomi Mikro Tentang Hukum Pidana Indonesia,Prenadamedia, Jakarta,h. 49. 
Jurnal Hukum Saraswati (JHS)Volume. 03, Nomor 02, (2021)

FAKULTAS HUKUM UNMAS DENPASAR

ISSN (Cetak) : 2715-758X ISSN (Online): 2720-9555

Doi: https://doi.org/10.36733/jhshs.v2i2

https://e-journal.unmas.ac.id/index.php/JHS

pada poin 4 menerangkan "Apabla para pihak yang terlibat bersikap proaktif dan telah mengembalikan seluruh kerugian keuangan negara, maka dapat dpertimbangkan untuk kelanjutan proses hukumnya dengan memperhatikan kepentingan stabilitas roda pemerintahan daerah setempat dan kelancaran pembangunan nasional".

Bahwa ketentuan poin 4 ini berdimensi politik ekonomi dimana pengembalian kerugian keuangan negara pada tahap penyelidikan dapat dijadikan pertimbangan dalam penanganan perkara. Termasuk jumlah kerugian keuangan kecil dengan pengembalian demi mewujudkan stabilitas keamanan suatu daerah. Bahwa ketentuan ini sebenarnya tidak sinkronisasi dengan ketentuan Pasal 4 UU No. 31 Tahun 1999 Tentang Pemberantasan Tindak Pidana Korupsi yang pada ntinya menyebutkan "pengembalian kerugian keuangan negara tidak menghapus perbuatan pidana yang terjadi”.

- Surat Edaran Jaksa Agung Muda Tindak Pidana Khusus Nom

- or : B-945/F/Fjp/05/2018 Tanggal 04 Mei 2018 Perihal Petunjuk Teknis Pola Penanganan Perkara Tindak Pidana Khusus yang berkualitas. Bahwa surat tersebut pada intinya menerangkan pada poin :

III. Pola Penanganan Perkara Tindak Pidana Khusus

A. Kejaksaan Republik Indonesia
merupakan
pemerintahan Lembaga
melaksanakan kekuasaan negara
dibidang penuntutan serta
kewenangan lain berdasarkan

\begin{abstract}
undang-undang. Kejaksaan sebagai suatu Lembaga pemerintahan dalam pelaksanaan tugas, fungsi dan kewenangan penegakan hukum pidana baik secara represif maupun preventif merupakan upaya maksimal dalam rangka mencapai perlindungan masyarakat dan mencapai kesejahteraan masyarakat yang tercermin dalam kebijakan pembangunan nasional.
\end{abstract}

Korelasi strategis antara penegakan hukum dan kebijakan pembangunan nasional dapat diimplementasikan oleh jajaran tindak pdana khusus dengan melakukan upaya pencegahan dan penindakan tindak pidana khusus, sebagai berikut :

1.

2.

3. $\quad \cdots \cdots$

4. $\quad$........

5. Penindakan tindak pidana korupsi dan tindak pidana khusus lainnya tidak hanya berorientasi pada pemidanaan / hukuman badan, tetapi juga pada penyelamatan / pengembalian kerugian keuangan negara;

B. Parameter perkara tindak pidana khusus yang dikategorikan sebagai perkara besar (bigfish)

C. Tahap-tahap penanganan perkara tindak pidana khusus yang berkualitas

Angka 3. Huruf $h$ yang menerangkan "hasil penyelidikan harus memberikan gambaran yang jelas apakah perkara tersebut merupakan perkara big fish atau bukan, sehingga apabila hasil 
Jurnal Hukum Saraswati (JHS)Volume. 03, Nomor 02, (2021)

FAKULTAS HUKUM UNMAS DENPASAR

ISSN (Cetak) : 2715-758X ISSN (Online): 2720-9555

Doi: https://doi.org/10.36733/jhshs.v2i2

https://e-journal.unmas.ac.id/index.php/JHS

\section{3}

penyelidikan diputuskan untuk ditindaklanjuti dengan penyidikan, .............."

Bahwa aturan tersebut tersirat ketentuan yang mengatur mengenai Patty Corruption. Dimana pada poin A angka 5 dengan jelas disebutkan kejaksaan "Penindakan tindak pidana korupsi dan tindak pidana khusus lainnya tidak hanya berorientasi pada pemidanaan / hukuman badan, tetapi juga pada penyelamatan / pengembalian kerugian keuangan negara". Bahwa penindakan bukanlah premium action yang dikehendaki untuk dilakukan namun juga tujuan restorasi. Sedangkan poin B jelas menerangkan bahwa penanganan perkara yang dikehendaki untuk diproses adalah perkara dengan parameter big fish (perkara besar). Sedangkan apabila kita menafsirkan secara a contrario maka diketahui maksud pembentukan aturan tersebut adalah pengutamaan perkara yang bersifat Big Fish.

Bahwa dari ketentuan tersebut diatas, terlihat kebijakan pidana (criminal policy) penanganan perkara patty corruption berdasarkan asas kemanfaatan yang menekankan pada pengembalian kerugian keuangan negara (tujuan restorasi) dalam suatu penyelesaian perkara. Hal ini selaras dengan teori economy approach to law yang menggunakan penilaian ekonomi dalam suatu perkara dilihat dari cost and benefitnya.

\section{Simpulan dan Saran}

Bahwa Teori Economy Analysis of Law atau yang disebut sebagai aplikasi teori ekonomi untuk analisis hukum merupakan teori yang mempergunakan konsep-konsep ekonomi untuk menjelaskan efek dari hukum itu sendiri. Analisa ilmu ini menggunakan kerangka teoritis metode ilmu ekonomi guna menganalisis aturan dan hukum yang memungkinkan menarik kesimpulan tentang keinginan manusia dan segala konsekuensi dari segi hukum dan bagaimana sebaiknya bentuk pengaturan hukumnya. Teori ini berakar pada teori hukum sebagai integrasi dan teori utilitarian. Yang menekankan pada cost and benefit dalam penanganan suatu perkara.

Bahwa Kejaksaan RI sudah memiliki aturan internal yang mengakomodir penanganan perkara berasaskan kemanfaatan dengan penekanan pengembalian kerugian keuangan negara (tujuan restorasi) sebagai aspek pengutamaan. Bahwa aturan internal tersebut memberikan ruang penanganan perkara secara non penal. 
Jurnal Hukum Saraswati (JHS)Volume. 03, Nomor 02, (2021)

FAKULTAS HUKUM UNMAS DENPASAR

ISSN (Cetak) : 2715-758X ISSN (Online): 2720-9555

Doi: https://doi.org/10.36733/jhshs.v2i2

https://e-journal.unmas.ac.id/index.php/JHS

54

\section{Daftar Pustaka}

\section{Buku}

Atmasasmita, Romly, \& Wibowo, Kodrat, 2016, Analisis Ekonomi Mikro Tentang Hukum Pidana Indonesia, Prenadamedia, Jakarta

Gunawan, T.J, 2015, Konsep Pemidanaan Berbasis Nilai Kerugian Ekonomi, GENTA Press, Yogyakarta

Maringka, Jan. S, 2017, Reformasi Kejaksaan dalam Sistem Hukum Nasional, Sinar Grafika, Jakarta

Ramadhan, Choky, 2016, Pengantar Analisis Ekonomi dalam Kebijakan Pidana di Indonesia, Institue for Criminal Justice Reform (ICJR), Jakarta

Sugianto, Fajar, 2015, Economic Approach to Law : Seri Analisis Keekonomian Tentang Hukum, seri II, Prenadamedia, Jakarta

2014, Economic Analysis of Law : Seri Analisis Keekonomian Tentang Hukum, seri I, Kencana, Jakarta

Tanya, Bernald L, Simanjuntak, Yoan N, \&Hage, Markus Y, 2012, Teori Hukum Strategi Tertib Manusia Lintas Ruang dan Generasi, Genta Publishing, Yogyakarta

Toegarisman, M. Adi, 2018, Pemberantasan Korupsi dalam
Proyek Strategis Nasional, Kompas Media, Jakarta

2016,

Pemberantasan Korupsi dalam

Paradigma Efisiensi, Kompas

Media Nusantara, Jakarta

\section{Peraturan Perundang-Undangan}

Undang-Undang Republik Indonesia

Nomor 16 Tahun 2004 Tentang

Kejaksaan Republik Indonesia

Undang-Undang Republik Indonesia

Nomor 7 Tahun 2006 Tentang

Pengesahan United Nations

Convention Against

Corruption, 2003 (Konvensi

Perserikatan Bangsa-Bangsa

Anti Korupsi, 2003)

Undang-Undang Republik Indonesia

Nomor 31 Tahun 1999 Tentang

Pemberantasan Tindak Pidana

Korupsi

Undang-Undang Republik Indonesia

Nomor 20 Tahun 2001 Tentang

Perubahan Atas Undang-

Undang Nomor 31 Tahun 1999

Tentang Pemberantasan Tindak

Pidana Korupsi

Undang-Undang Republik Indonesia

Nomor 17 Tahun 2003 Tentang

Keuangan Negara

Undang-Undang Republik Indonesia

Nomor 1 Tahun 2004 Tentang

Perbendaharaan Negara 
Jurnal Hukum Saraswati (JHS)Volume. 03, Nomor 02, (2021)

FAKULTAS HUKUM UNMAS DENPASAR

ISSN (Cetak) : 2715-758X ISSN (Online): 2720-9555

Doi: https://doi.org/10.36733/jhshs.v2i2

https://e-journal.unmas.ac.id/index.php/JHS

Undang-Undang Republik Indonesia

Nomor 19 Tahun 2003 Tentang

Badan Usaha Milik Negara

Undang-Undang Republik Indonesia

Nomor 40 Tahun 2007 Tentang

Perseroan Terbatas

Surat Edaran Jaksa Agung Muda

Tindak Pidana Khusus Nomor :

B-1113/F/Fd.1/05/2010 tanggal

18 Mei 2010 perihal Prioritas

dan pencapaian dalam

penanganan perkara tindak

pidana korupsi

945/F/Fjp/05/2018 Tanggal 04

Mei 2018 Perihal Petunjuk Teknis

Pola Penanganan Perkara Tindak

Pidana Khusus yang berkualitas

\section{Jurnal}

Iswara, I Made Agus Mahendra, 2013, Mediasi Penal Penerapan Nilai-Nilai Restorative Justice dalam Penyelesaian Tindak Pidana Adat Bali, Tesis Program Studi Hukum dan Sistem Peradilan Pidana Pasca Sarjana Fakultas Hukum Universitas Indonesia

Surat Edaran Jaksa Agung Muda Tindak Pidana Khusus No : B765/F/Fd/04/2018 20 April 2018 Mei 2018 Perihal Petunjuk Tekns Penanganan Perkara Tindak Pidana Korupsi Tahap Penyelidikan

Surat Edaran Jaksa Agung Muda Tindak Pidana Khusus Nomor : B-

Tim Peneliti Pusat Litbang Kejagung, Penghentian Penyidikan dan Penuntutan Perkara Korupsi dalam Kaitannya dengan Asas Kepastian Hukum, Keadilan, dan Kemanfaatan, dalam Jurnal Bina Adhyaksa, Vol. II, No. 1, Maret 2011 